\title{
强关联量子杂质体系的精确模拟
}

郑晓

中国科学技术大学, 合肥微尺度物质科学国家研究中心, 合肥 230026

E-mail: xz58@ustc.edu.cn

2018-08-30 收稿, 2018-10-03 修回, 2018-10-09 接受, 2018-10-31 网络版发表

国家重点研发计划(2016YFA0400900，2016YFA0200600)、国家自然科学基金(21573202)和中国科学技术大学重要方向培育基金(2340000074) 资助

摘要对复杂凝聚态体系中的局域量子态的精确描述，以及对量子态在外场、环境调控下的响应与演化机制的 深刻理解, 对量子功能材料与器件的构筑与设计有着重要的基础性意义. 然而, 如何精确刻画复杂材料体系中的 量子相干、关联、纠缠等特性, 对理论研究而言是个传统难题. 本文从全新的视角, 即“开放量子体系”的角度来研 究复杂凝聚态体系中的量子态. 简要介绍了近年来我们基于严格的量子耗散理论发展得到的级联运动方程方法, 以及该方法在实验高度关注的强关联量子杂质体系的计算模拟研究方面的应用.

关键词强关联体系, 开放量子体系, 级联运动方程, 近藤效应, 分子磁体

随着科学技术的不断发展, 人们对微观世界的 研究已从原子层次深人到了量子层次. 针对量子体 系的研究, 无论是对物理、化学、材料学等传统学科, 还是对量子信息、量子计算等新兴领域, 都具有重要 的基础性意义. 特别地, 量子功能材料与器件的构筑 与设计已成为实验前沿的一个热点. 例如, 通过改变 物质材料的组成、结构, 使其呈现新奇的量子现象或 效应; 或是通过调控环境、外场等, 对物质材料中的 量子态进行精准操控. 在实验进展之外, 理论研究也 至关重要. 为了深刻理解实验中观测到的量子行为 与特性, 需要从理论上阐明量子态形成、演化的机制 和规律. 此外, 通过理论模拟, 还可得到仅凭实验手 段难以获取的细节信息, 从而为实验研究提供重要 的理论依据和指引.

近年来, 分子、团簇、纳米结构、量子点等多种 形态的量子体系在实验上得到了广泛的关注. 这些 微纳体系可具有局域电荷态或自旋态. 以分子磁体 为例, 有机金属分子的过渡金属原子中心可含有自
旋未配对的 $\mathrm{d}, \mathrm{f}$ 电子, 可用于构建自旋量子比特, 从 而有望成为量子存储、调控器件的原型. 上述量子体 系有着鲜明的共同特征：体系内部的局域量子态仅 涉及少数自由度; 同时, 体系外部的宏观材料环境 (如金属电极、衬底材料等)可对其量子特性(相干、关 联、纠缠等)产生显著影响. 因此, 理论上常用量子杂 质模型来刻画这类量子体系, 而量子杂质体系的高 精度数值模拟也成为了理论研究的关键.

量子杂质模型的精确求解是计算凝聚态物理的 一个传统难题. 特别是当体系中存在较强的电子-电 子相互作用时, 可呈现出显著的多体关联效应. 为了 准确描述电子强关联效应, 人们已发展了多种计算 方法, 包括数值重整化群方法 ${ }^{[1]}$ 、量子蒙特卡洛方 法 ${ }^{[2]}$ 等. 这些方法已在强关联材料的物性模拟方面取 得了巨大的成功. 然而, 近年来量子态操控实验的最 新进展为理论研究提出了新的挑战. 这是由于传统 方法在描述非平衡量子体系, 特别是环境、外场调控 作用下量子态的含时演化等方面存在较大的局限性. 
因此, 亟需发展普适、精确、高效的新方法, 以为相 关实验研究提供有力的理论工具.

量子杂质体系是典型的开放体系. 以当前实验 前沿的热点之一——金属表面吸附的分子磁体一一为 例. 其中, 分子磁体中的局域自旋态是实验研究的首 要对象; 金属衬底虽然不是量子态的主要载体, 但它 对吸附分子的空间与电子结构有着重要影响. 同时, 对吸附分子而言, 金属衬底也构成了热库与电子库 环境. 在分子与衬底环境之间存在着能量传递、电子 转移、量子退相干等耗散过程, 这在很大程度上决定 了分子局域自旋态的性质与动力学. 鉴于材料环境 在量子杂质体系中的重要作用, 以及它近乎无限的 自由度为理论模拟造成的困难, 我们选择将量子统 计与量子动力学方法相结合, 来研究量子杂质问题.

\section{1 级联运动方程方法的发展}

研究开放量子体系在环境涨落作用下的耗散动 力学的理论方法称为量子耗散方法. 早期的量子耗 散方法多是借助微扰论来刻画体系与环境之间的耗 散过程. 因此, 相应的理论计算结果仅适用于体系环境弱耦合的情况. 约 30 年前, 谷村吉隆和久保亮 五 $^{[3,4]}$ 提出了具有级联方程组 (HEOM) 形式的量子耗 散方法. 其后, 邵久书课题组 ${ }^{[5]}$ 通过对体系-环境耦 合进行随机解耦, 以及严以京和徐瑞雪课题组 ${ }^{[6,7]}$ 等 通过费曼-弗农路径积分方法 ${ }^{[8]}$, 分别推导出了形式 上严格的HEOM. 严以京课题组 ${ }^{[9]}$ 进一步将HEOM的 适用范围从玻色子库环境推广到费米子库环境, 使 得 HEOM方法可用于研究强关联电子体系与问题. 近年来, HEOM方法已在非线性多维光谱、能量转移 与热输运、电荷转移与输运、化学反应路径与速率、 量子比特操控等方面得到了广泛的应用.

HEOM的数学形式是线性微分方程组, 其基本 变量为体系的约化密度矩阵和辅助密度矩阵(图 1), 它们涵盖了体系量子态演化的关键信息. 对于服从 高斯统计的环境(如自由电子库等), HEOM理论不含 任何近似, 是一个严格的理论. 它以非微扰的形式呈 现了多体相互作用、环境涨落与耗散, 以及非马尔科 夫记忆等物理内涵, 为量子杂质体系的研究提供了 严格而普适的理论框架.

HEOM方法可直接用于量子杂质模型的数值模 拟. 它可处理任意形式的多体相互作用、模拟体系在 任意含时外场下的响应, 以及计算多种平衡态或非

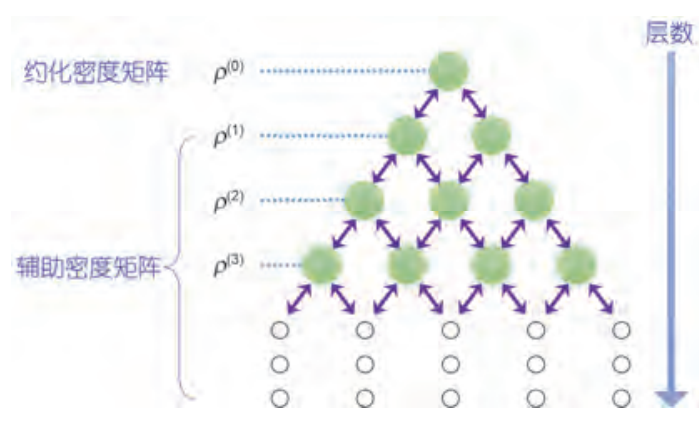

图 1 级联运动方程组示意图. 每个绿色圆盘代表一个密度矩阵, 紫 色双向箭头代表密度矩阵之间存在耦合. $\rho^{(n)}$ 代表第 $n$ 层的辅助密度矩 阵 ${ }^{[10]}$

Figure 1 Schematic of HEOM. Each green disk represents a density matrix, and each purple double-arrow indicates the existence of coupling between two density matrices in the hierarchy. $\rho^{(n)}$ denotes an auxiliary density matrix at the $n$th tier $^{[10]}$

平衡态性质 ${ }^{[11,12]}$. HEOM简洁的数学形式使得它在模 拟量子态的相干演化等方面具有天然优势. 此外, 当 体系处于稳态时，微分方程组可转化为线性方程组, 而后者可通过拟极小残差法 ${ }^{[13]}$ 等算法求解，从而很 方便地得到体系的稳态解. 在实际计算中, 为了使级 联方程组封闭，必须以某种方式对方程组进行截断. 大量计算表明, HEOM的数值结果通常随着截断层数 的提高快速收敛到精确值. 特别的，对于由费米子构 成的环境(如电子库等), 较低层截断的HEOM已可保 证计算得到的体系性质的精确性，这是由于泡利不 相容原理限制了体系与费米子环境之间的耗散模 式 ${ }^{[13]}$. 相比于传统计算方法, HEOM方法无论是在计 算精度，还是在数值收玫性、稳定性，以及实用性、 便捷性等方面都具有独特的优越性.

\section{2 级联运动方程方法的应用}

本课题组 ${ }^{[14]}$ 自主开发了计算机数值程序HEOMQUICK, 经过不断优化和完善, 基本实现了 HEOM方 法的各种应用. 为了尽可能提高程序的计算效率，本 课题组发展了一系列先进算法，包括：环境自能函数 的最优分解方案 ${ }^{[15]}$ 、密度矩阵稀疏化存储与计算方 案 ${ }^{[16]}$ 、级联方程组的高效截断方案 ${ }^{[16]}$ 等. HEOMQUICK程序可作为“量子杂质求解器”, 对强关联量 子杂质模型的关键性质进行高精度计算; 此外, 它也 可与密度泛函计算程序相结合, 实现从第一性原理出 发, 研究真实材料体系中的强关联效应与量子态操 控. 近年来, 我们应用HEOM-QUICK程序, 针对一系 列实验上高度关注的量子杂质体系与问题开展了研 
究. 以下将简要介绍HEOM方法与程序在强关联量子 杂质体系研究中的应用. 我们将从典型的模型体系出 发, 并着重阐述如何将HEOM方法与第一性原理计算 方法相结合，实现对真实体系的理论计算模拟.

首先, 我们对一些重要的量子杂质模型进行了 研究. 例如, 对含有强电子-电子相互作用的安德森 杂质模型, 我们计算了杂质的电子占据数、电流、热 流、磁化率、态密度、相互作用自能等重要的热力学 与动力学性质, 并揭示了体系性质随各能量参数的 变化规律 ${ }^{[17 ~ 19]}$. 特别是当环境温度足够低时, 杂质 上布居电子的局域自旋可被环境中巡游电子的自旋 所屏蔽, 从而导致杂质-环境纠缠态一一近藤态的产 生. 近藤态是典型的强关联电子态, 计算得到的杂质 态密度与微分电导谱均清晰的显现近藤共振峰, 而 对近藤特征 (如电导大小随温度变化的标度关系等) 的数值刻画也精确符合解析理论的预言 ${ }^{[19]}$. 本课题 组 ${ }^{[20]}$ 进一步对一些具有周期性结构的强关联模型体 系进行了计算. 在动力学平均场理论框架下, 以 HEOM方法作为杂质求解器, 计算了赫伯德模型的 电子结构. 计算结果清晰的展现了莫特金属-绝缘体 相变过程: 在低温下, 随着电子库伦排斥能的增加, 体系态密度在费米能级处的准粒子峰突然变弱甚至 完全消失(图2). 该相变过程是电子强关联效应的重 要体现.

在此基础上, 我们对量子点体系在外场调控下 的非平衡响应进行了研究. 例如, 热电势是热电器件 的一个关键物理量. 它描述了在一定温度梯度下, 器 件中产生的热致电流的方向和大小. 理论推导发现, 量子点的热电势由以费米能级为中心、温度为展宽的 一个小能量窗口内的态密度分布决定. 由此, 本课题 组 ${ }^{[21]}$ 提出了一个调控量子点热电势的新方案, 即通 过调节量子点的电子能级差或电子库伦能来改变费 米能级处的态密度, 从而调控热电势的符号和大小. 我们应用HEOM方法精确计算了量子点在温度梯度 下的热致电流, 从而验证了上述方案的有效性. 此 外, 我们还研究了量子点体系在含时外场驱动下的 动态响应. 计算表明, 当量子点中存在强关联电子态 时, 其动力学行为与体系的演化历史密切相关. 例 如, 我们计算了量子点在交变电压下动态电流响应. 当量子点体系中存在近藤电子态时, 其含时电流-电 压响应曲线可呈现类似磁滞回线的形态, 这表明近 藤电子态可引起显著的忆阻效应 ${ }^{[22]}$. 对量子点非平

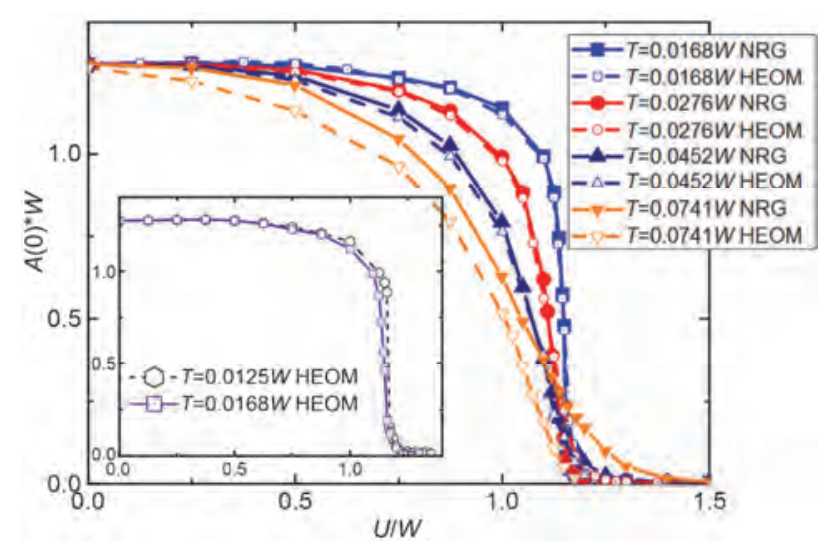

图 2 (网络版彩色) 在动力学平均场理论框架下, 用HEOM方法作为杂 质求解器计算赫伯德模型的态密度, 并与数值重整化群 $(\mathrm{NRG})$ 结果 比较 ${ }^{[20]}$. 主图为费米能级处的态密度随电子库伦能的变化. 在低温 下, HEOM与NRG计算结果高度吻合; 而在较高温度下, HEOM结果 保持了高精度, 而 NRG结果呈现较明显的误差. 内插图为低温下 HEOM结果, 可观察到当库伦能增大到某个阈值(图中为 1.2 左右)时, 态密度突然急剧减小到零, 表明体系经历了莫特金属-绝缘体相变

Figure 2 (Color online) Density of states of a Hubbard model calculated by the dynamical mean-field theory with the HEOM approach as the impurity solver. The results are compared in parallel with those obtained by the NRG method ${ }^{[20]}$. The main panel depicts the variation of density of states versus the electron Coulomb energy. At low temperatures, the HEOM and NRG results agree closely with each other. At high temperatures, while the HEOM method preserves the high accuracy, the NRG results exhibit conspicuous error. The inset highlights the HEOM results at low temperatures. It is shown clearly that, as the Coulomb energy increases up to a certain threshold value (about 1.2), the density of states diminishes drastically to nearly zero, indicating that the system is experiencing a Mott metal-insulator transition

衡响应的计算揭示了量子相干和量子关联可具有协 同效应, 该效应可能为量子点器件在量子信息、量子 计算等领域的应用提供新的思路.

我们将 HEOM方法与密度泛函方法 (DFT) 相结 合, 从而实现了从第一性原理出发, 来研究金属表面 吸附的分子磁体中的量子态. 实验上发现, 对于吸附 在 $\mathrm{Au}$ 表面的钴酞菁 $(\mathrm{CoPc})$ 分子, 当酞菁环的外层氢 原子被去除后，其扫描隧道电导谱在低温下呈现显 著的近藤特征峰 ${ }^{[23]}$. 根据峰高与峰宽随温度的变化 关系可以导出该表面分子体系的近藤温度高达 200 $\mathrm{K}$. 为理解这一奇异的实验现象, 本课题组 ${ }^{[24]}$ 构建了 该表面分子复合体系的原子模型, 并进行了细致的 计算模拟. DFT计算表明, Co原子 $\mathrm{d}_{z^{2}}$ 轨道上占据着 1 个 自旋未配对的电子, 从而在Co原子中心形成了局域 自旋分布. 同时, 由于 $\mathrm{Co}$ 原子的 $\mathrm{d}_{z^{2}}$ 轨道在垂直表面 的方向上伸展, 使得它与 $\mathrm{Au}$ 表面的电子能态之间存 在较强的耦合. 这种耦合作用使得Co原子中心处的 
局域自旋被 $\mathrm{Au}$ 衬底中的自由电子的自旋所屏蔽, 导 致了近藤态的形成. 我们根据DFT计算得到的能量 参数构建了安德森单杂质模型, 并用HEOM方法模 拟了实验条件下的扫描隧道电导谱(图3). 计算得到 的微分电导曲线以及由之导出的近藤特征温度均与 实验测量结果高度吻合. 因此, 我们的DFT+HEOM 计算揭示了表面分子磁体的局域自旋态和近藤关联 态的形成机制.

最近, 实验上利用扫描隧道显微镜的原子级针 尖, 实现了对吸附在 $\mathrm{Pb}$ 表面的铁卟啉 $(\mathrm{FeOEP})$ 分子自 旋态的操控. 通过改变针尖到分子中心 $\mathrm{Fe}$ 原子的距 离, 可在毫电子伏级的精度上连续调控 $\mathrm{FeOEP}$ 分子的 磁各向异性能; 同时, 当针尖逐渐接近分子时, 体系 内的近藤关联强度也呈现出显著的非单调性变化 ${ }^{[25]}$. 因此, 表面分子磁体的自旋激发和近藤关联之间存在 复杂的竞争关系, 这两种物理机制的相对强弱可在针 尖调控作用下显著变化. 为了深彻理解上述物理机制 的竞争与针尖的调控作用, 我们用DFT方法模拟了针 尖接近分子的过程中 $\mathrm{FeOEP} / \mathrm{Pb}$ 复合体系的空间与电 子结构的演变; 以及用高精度的量子化学方法一一完 全活性空间自洽场方法(CASSCF) 一一计算了吸附分 子磁各向异性能的变化. 本课题组 ${ }^{[26]}$ 进一步用 HEOM方法模拟了针尖调控过程中微分电导谱的变 化(图4). 上述计算结果均精确复现了实验观测. 计 算模拟揭示了在针尖逐渐接近 $\mathrm{Pb}$ 表面的过程中, 分 子中心 Fe原子在针尖的范德华力作用下先远离后靠
近 $\mathrm{Pb}$ 表面, 而 $\mathrm{Fe}$ 原子 $\mathrm{d}$ 轨道与 $\mathrm{Pb}$ 表面电子态的耦合强 度由此发生先减小再增大的非单调变化, 从而导致 近藤关联强度发生先减弱后增强的相应变化. 当近 藤关联强度增加到一定程度后, 微分电导谱不再呈 现自旋激发信号. 由此，阐明了环境 $(\mathrm{Pb}$ 衬底、针尖) 的存在与调控对表面分子磁体的自旋激发和近藤关 联等关键性质的重要影响.

\section{3 小结与展望}

随着理论前沿的发展、数值算法的改进, 以及 HEOM-QUICK程序的完善, HEOM方法正在成为强 关联量子杂质体系的标准计算方法之一，而DFT+ HEOM方法更为研究真实量子材料与器件, 以及模 拟真实实验条件下的量子态操控提供了有力的理论 工具. 值得注意的是, HEOM方法在计算效率、应用 范畴等方面仍有巨大的提升空间. 例如, 对量子功能 器件而言, 其在低温环境下的性质与调控尤为重要. 这是由于环境的热涨落在低温下弱化, 从而对相干、 关联、纠缠等量子效应的抑制作用显著减小. 然而, 现有 HEOM方法的计算耗费随环境温度的降低急剧 增长. 为精确描述低温环境的影响, 需要用较多的指 数函数来展开环境自能, 这导致级联方程组中包含 的辅助密度矩阵数目大大增加, 从而为数值模拟造 成困难. 因此, 有必要针对低温环境, 发展新的自能 分解方案, 以研究低温条件下的强关联杂质体系. 此 外, 大量计算模拟表明, 材料环境的存在对局域量子

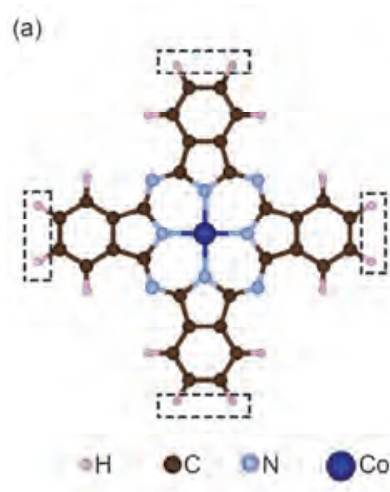

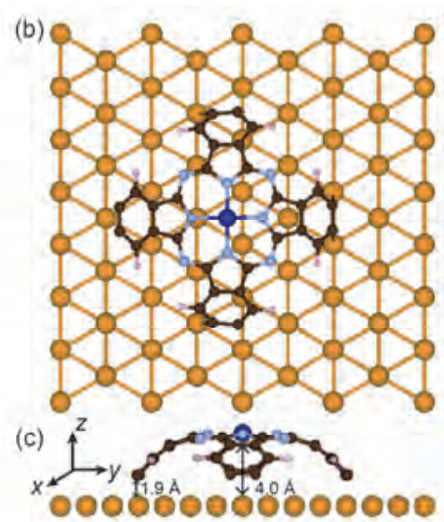

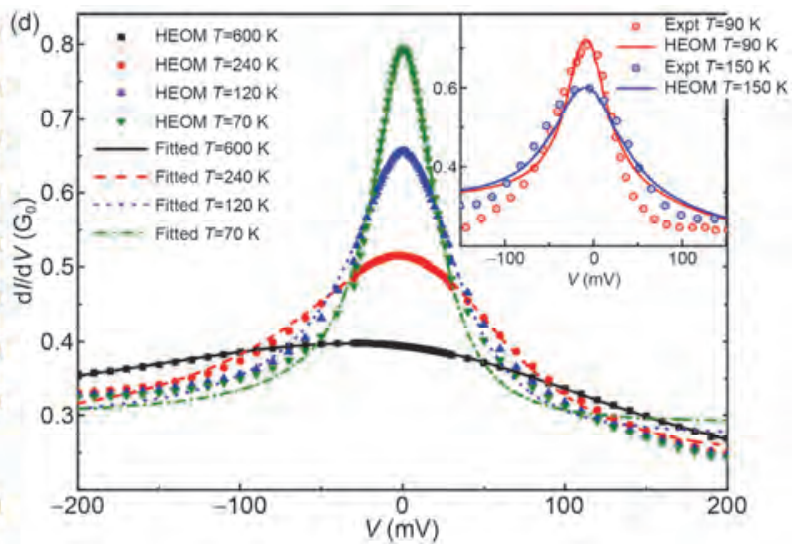

图 3 (网络版彩色) $\mathrm{Au}$ 表面吸附的CoPc分子的计算研究. (a) CoPc分子结构示意图; (b) 外层氢原子去除后的CoPc分子吸附在 $\mathrm{Au}(111)$ 表面的顶 视; (c) 侧视图; (d) DFT+HEOM计算得到的扫描隧穿电导谱, 内插图为计算值与实验测量值的比较 ${ }^{[24]}$

Figure 3 (Color online) Computational study on a CoPc molecule adsorbed on the Au surface. (a) Geometric structure of a CoPc molecule; (b) top view and (c) side view of a dehydrogenated CoPc molecule adsorbed on an Au(111) surface; and (d) scanning tunneling differential conductance spectra calculated by the DFT+HEOM method, where the inset compares the numerical results with the experimental measurements ${ }^{[24]}$ 

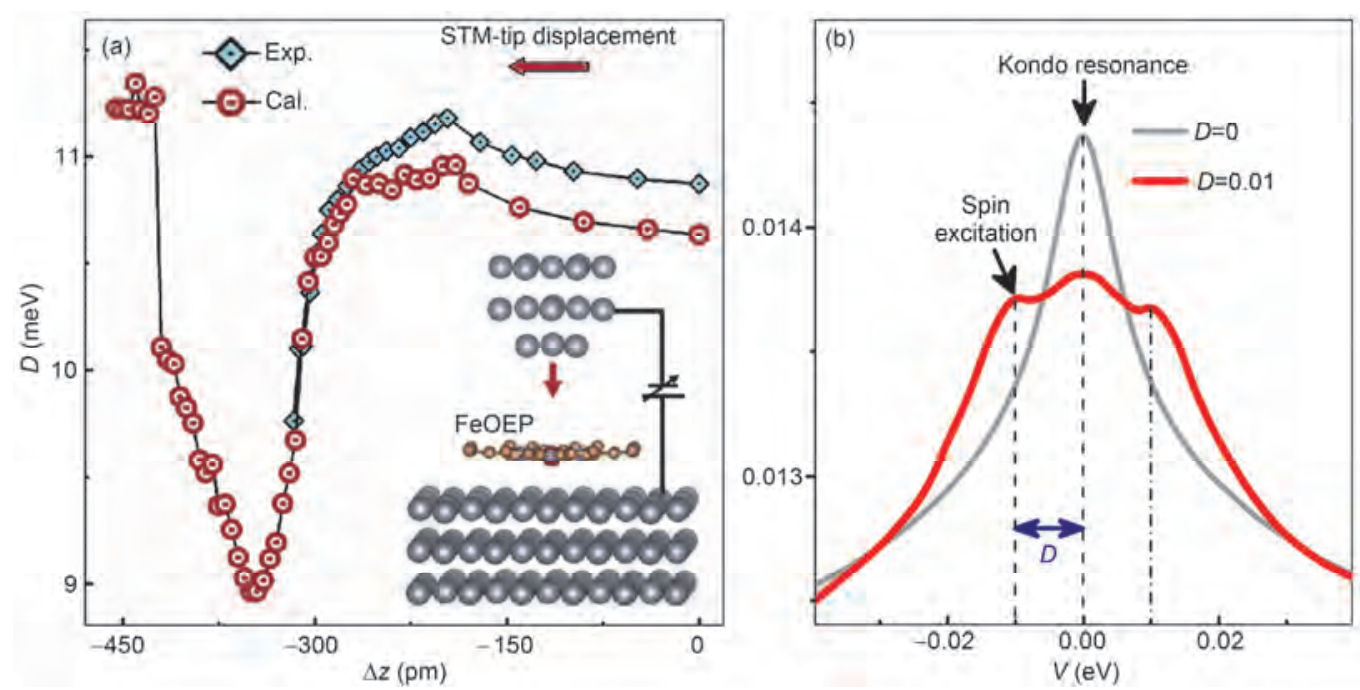

图 4 (网络版彩色) $\mathrm{Pb}$ 表面吸附的FeOEP分子的计算研究. (a) DFT+CASSCF计算得到的分子磁各向异性能随针尖位移的变化以及与实验测量 值的比较. 右下图为扫描隧道显微镜针尖接近吸附在 $\mathrm{Pb}(111)$ 表面的FeOEP分子; (b) HEOM计算得到的微分电导谱, 其中零偏压处的峰即是近 藤特征峰 ${ }^{[26]}$

Figure 4 (Color online) Computational study on a FeOEP molecule adsorbed on the Pb surface. (a) Magnetic anisotropy energy of the adsorbed molecule versus tip displacement. Numerical results obtained by the DFT+CASSCF method are compared with the experimental measurement. Lower-right panel: the tip of a scanning tunneling microscope approaching a FeOEP molecule adsorbed on a $\mathrm{Pb}(111)$ surface. (b) Differential conductance spectra calculated by the HEOM method, where the peak at zero bias is the characteristic Kondo peak ${ }^{[26]}$

态有着关键影响，而在当前的实验研究中，通过改变 环境因素来实现量子调控的尝试仍然较少. 在这个
方向上理论研究大有可为, 特别是基于第一性原理 的计算模拟，可望为相关实验提供新的思路.

\section{参考文献}

1 Wilson K G. The renormalization group: Critical phenomena and the Kondo problem. Rev Mod Phys, 1975, 47: 773

2 Hirsch J E, Fye R M. Monte Carlo method for magnetic impurities in metals. Phys Rev Lett, 1986, 56: 2521

3 Tanimura Y, Kubo R. Time evolution of a quantum system in contact with a nearly Gaussian-Markoffian noise bath. J Phys Soc Jpn, 1989, 58: 101-114

4 Tanimura Y. Nonperturbative expansion method for a quantum system coupled to a harmonic-oscillator bath. Phys Rev A, 1990, 41: 6676-6687

5 Yan Y A, Yang F, Liu Y, et al. Hierarchical approach based on stochastic decoupling to dissipative systems. Chem Phys Lett, 2004, 395: 216-221

6 Xu R X, Cui P, Li X Q, et al. Exact quantum master equation via the calculus on path integrals. J Chem Phys, 2005, 122: 041103

7 Xu R X, Yan Y J. Dynamics of quantum dissipation systems interacting with bosonic canonical bath: Hierarchical equations of motion approach. Phys Rev E, 2007, 75: 031107

8 Feynman R P, Vernon F L. The theory of a general quantum system interacting with a linear dissipative system. Ann Phys, 1963, 24: 118

9 Jin J, Zheng X, Yan Y J. Exact dynamics of dissipative electronic systems and quantum transport: Hierarchical equations of motion approach. J Chem Phys, 2008, 128: 234703

10 Han L, Zhang H D, Zheng X, et al. On the exact truncation tier of fermionic hierarchical equations of motion. J Chem Phys, 2018, 148: 234108

11 Zheng X, Jin J, Yan Y J. Dynamic electronic response of a quantum dot driven by time-dependent voltage. J Chem Phys, 2008, 129: 184112

12 Zheng X, Jin J, Welack S, et al. Numerical approach to time-dependent quantum transport and dynamical Kondo transition. J Chem Phys, 2009, 130: 164708 
13 Freund R W, Nachtigal N M. QMR: A quasi-minimal residual method for non-Hermitian linear systems. SIAM J Numer Math, 1991, 60: 315-339

14 Ye L Z, Wang X, Hou D, et al. HEOM-QUICK: A program for accurate, efficient, and universal characterization of strongly correlated quantum impurity systems. WIREs Comput Mol Sci, 2016, 6: 608-638

15 Ye L Z, Zhang H D, Wang Y, et al. Low-frequency logarithmic discretization of the reservoir spectrum for improving the efficiency of hierarchical equations of motion approach. J Chem Phys, 2017, 147: 074111

16 Hou D, Wang S K, Wang R, et al. Improving the efficiency of hierarchical equations of motion approach and application to coherent dynamics in Aharonov-Bohm interferometers. J Chem Phys, 2015, 142: 104112

17 Wang S K, Zheng X, Jin J, et al. Hierarchical Liouville-space approach to nonequilibrium dynamical properties of quantum impurity systems. Phys Rev B, 2013, 88: 035129

18 Ye L, Hou D, Zheng X, et al. Local temperatures of strongly-correlated quantum dots out of equilibrium. Phys Rev B, 2015, 91: 205106

19 Li Z H, Tong N H, Zheng X, et al. Hierarchical Liouville-space approach for accurate and universal characterization of quantum impurity systems. Phys Rev Lett, 2012, 109: 266403

20 Hou D, Wang R, Zheng X, et al. Hierarchical equations of motion for an impurity solver in dynamical mean-field theory. Phys Rev B, 2014, 90: 045141

21 Ye L Z, Hou D, Wang R, et al. Thermopower of few-electron quantum dots with Kondo correlations. Phys Rev B, 2014, 90 : 165116

22 Zheng X, Yan Y J, Di Ventra M. Kondo memory in driven strongly correlated quantum dots. Phys Rev Lett, 2013, 111: 086601

23 Zhao A, Li Q, Chen L, et al. Controlling the Kondo effect of an adsorbed magnetic ion through its chemical bonding. Science, 2005, 309: 1542-1544

24 Wang Y, Zheng X, Li B, et al. Understanding the Kondo resonance in the d-CoPc/Au(111) adsorption system. J Chem Phys, 2014, 141: 084713

25 Heinrich B W, Braun L, Pascual J I, et al. Tuning the magnetic anisotropy of single molecules. Nano Lett, 2015, 15: 4024-4028

26 Wang X, Yang L, Ye L Z, et al. Precise control of local spin states in an adsorbed magnetic molecule with an STM tip: Theoretical insights from first-principles-based simulation. J Phys Chem Lett, 2018, 9: 2418-2425 


\title{
Precise simulation of strongly correlated quantum impurity systems
}

\author{
Xiao Zheng \\ Hefei National Laboratory for Physical Sciences at the Microscale, University of Science and Technology of China, Hefei 230026, China \\ E-mail: xz58@ustc.edu.cn
}

In recent years, nano-sized systems involving local charge or spin states have received wide interests because of their potential application in emerging fields such as quantum information and quantum computation. For instance, organometallic molecular complexes may serve as building blocks of quantum storage devices, because the spin-unpaired $\mathrm{d}$ or $\mathrm{f}$ electrons at transition metal centers may be employed to construct spin qubits. Moreover, if the system contains strong electron-electron interaction, the involving local quantum states are subject to prominent electron correlation effects (such as the Kondo effect). Theoretically, spatially confined nano-systems are often described by quantum impurity models. Thus the accurate prediction of the intrinsic properties of quantum impurity systems and the deep understanding on the response and evolution of local quantum states under external fields or in dissipative environment are fundamentally important for the design and fabrication of quantum devices.

The accurate characterization of quantum coherence, correlation, and entanglement in quantum impurity systems remains a great challenge. Enormous efforts have been made to achieve this goal. A variety of theoretical methods have been developed, including the numerical renormalization group method, the quantum Monte Carlo method, and many others. However, all the existing methods are subject to certain limitations regarding accuracy or efficiency. Therefore, we choose to view this problem from a new perspective- the perspective of open quantum systems. Over the past decade, we have developed a formally exact quantum dissipation theory, the hierarchical equations of motion (HEOM) theory, for fermionic open systems. The HEOM theory captures the combined effects of system-environment dissipation, many-body interaction, and non-Markovian memory in a nonperturbative manner. It is capable of addressing static and dynamic responses of system observables in both equilibrium and nonequilibrium situations. We have implemented the HEOM method in our self-designed computer program HEOM-QUICK. We have also devised a series of advanced algorithms which substantially enhance the numerical efficiency of HEOM. The HEOM-QUICK program thus provides an accurate, efficient, and versatile theoretical tool for the investigation of strongly correlated quantum impurity systems.

We have applied the HEOM method to study a variety of problems associated with quantum impurity systems. These include the intrinsic properties of quantum impurity models and lattice models, the transient current response of quantum dots to $a c$ voltages, the thermopower and local heating effect in nonequilibrium quantum dots, and the tuning of local spin states in adsorbed molecular magnets. In particular, the HEOM method has been combined with density functional theory (DFT) method, and thus allows for first-principles-based simulation on the precise tuning of local spin states in adsorbed magnetic molecules. Numerical simulations have discovered or reproduced many important quantum phenomena that are essential for relevant experiments, including the Kondo effect, Mott metal-insulator transition, quantum memristive effect, etc.

This paper gives a brief overview of our development of the HEOM method for fermionic open systems, as well as its applications to various strongly correlated quantum impurity systems.

strongly correlated systems, open quantum systems, hierarchical equations of motion, Kondo effect; molecular magnet

doi: 10.1360/N972018-00895 